\title{
Detection of Aspergillus fumigatus PCR products by a microtitre plate based DNA hybridisation
}

\author{
assay
}

\author{
H A Fletcher, R C Barton, P E Verweij, E G V Evans
}

\begin{abstract}
Aims-To develop a DNA based plate hybridisation assay for the detection of polymerase chain reaction (PCR) products amplified from Aspergillus fumigatus DNA; and to determine the sensitivity of this technique and compare it with Southern blotting.

Methods-A half-log dilution series of DNA extracted from $A$ fumigatus was amplified with specific primers, one of which was 5' end labelled with biotin. PCR products were subsequently detected by agarose gel electrophoresis, Southern blotting, and binding of the products to a streptavidin coated microtitre well, followed by non-radioactive colorimetric detection. Amplification was carried out 10 times for each DNA dilution and a plot of initial DNA concentration against signal intensity was made.
\end{abstract}

Results-A DNA concentration of $1.5 \mathrm{pg}$ could be detected by agarose gel electrophoresis and Southern blotting with a non-radioactively labelled aspergillus specific probe; $1.5 \mathrm{pg}$ was detectable by streptavidin binding of the PCR products to a microtitre plate. The signal from the microtitre plate detection was proportional to the amount of DNA in the PCR reaction on a $\log -\log$ scale between 100 and $1 \mathrm{pg}$ of DNA.

Conclusions-A DNA based plate hybridisation assay for the detection of $A$ fumigatus PCR products is as sensitive as Southern blotting. However, results are obtained in three hours rather than the three days required for agarose gel electrophoresis, blotting, hybridisation, and detection.

(F Clin Pathol 1998;51:617-620)

Keywords: aspergillosis; polymerase chain reaction; enzyme linked immunosorbent assay

Aspergillus fumigatus is a saprophytic fungus that can cause serious infections in patients, particularly those undergoing organ and bone marrow transplants and those with haematological malignancies. Invasive pulmonary aspergillosis is one of the commonest causes of death from infection in the immunocompromised host, ${ }^{1}$ with a mortality rate of up to $90 \%$. Although 16 aspergillus species are known to cause infection, ${ }^{2}$ the major species involved in aspergillosis is Aspergillus fumigatus. A fumigatus is ubiquitous in the environment and can be isolated from numerous sources such as air conditioning systems, soil, rotting compost, and fireproofing material. ${ }^{1}$ The route of entry is thought to be by the inhalation of airborne conidia, which are relatively small in diameter and can penetrate deep into the lung. ${ }^{3}$

The main difficulty in the management of invasive pulmonary aspergillosis is the diagnosis of the infection at an early stage of the disease, essential for successful treatment and the avoidance of empirical therapy. Establishing a clinical diagnosis of fungal infection in the immunocompromised host is difficult as the clinical presentation of invasive pulmonary aspergillosis is often non-specific and a positive aspergillus culture is found in only one third of patients with invasive aspergillosis before death. ${ }^{4}$

Serological tests for antibodies are usually not indicated in immunocompromised patients, while antigen detection using the latex agglutination test for galactomannan is at most $70 \%$ sensitive and $86 \%$ specific. $^{56}$ Enzyme linked immunosorbent assay (ELISA) tests for galactomannan are more sensitive but have a lower specificity. ${ }^{6}$ Attention is therefore now turning to molecular methods for the diagnosis of invasive aspergillosis by the detection of Aspergillus DNA.?

Polymerase chain reaction (PCR) assays targeting several regions of the $A$ fumigatus genome have been developed in various laboratories. ${ }^{8-15}$ Many have shown that PCR is a more sensitive method than culture for detecting A fumigatus in bronchoalveolar lavage fluid or sputa, ${ }^{11-15}$ and more recently blood. ${ }^{16}$ Detection of PCR product has mainly been by ethidium bromide stained agarose gel electrophoresis and Southern blotting. These methods of detection, although sensitive, are time consuming and the interpretation of results may be subjective. Microtitre plate based DNA hybridisation assays have been developed for the detection of chlamydia and candida DNA. ${ }^{17} 18$ The aim of our study was to develop a microtitre plate based assay for the rapid, quantitative detection of aspergillus PCR products.

\section{Methods}

CULTURE

Aspergillus fumigatus strain LM004, isolated from a patient with invasive aspergillosis, was grown at $37^{\circ} \mathrm{C}$ on a Sabouraud agar slope for two days. Spores were harvested by gently agitating with $1 \mathrm{ml} 0.5 \%$ Tween 20 , then $100 \mu$ of spore suspension was added to $50 \mathrm{ml}$ Sabouraud liquid medium and incubated overnight in a $37^{\circ} \mathrm{C}$ shaker at $120 \mathrm{rpm}$. 
ISOLATION OF DNA

Mycelial growth was obtained by filtration of the culture with a $0.45 \mu \mathrm{m}$ membrane filter. Using liquid nitrogen and pestle and mortar, $0.3 \mathrm{~g}$ of filtered mycelia was ground to a powder. Powdered mycelia were resuspended in $500 \mu \mathrm{l}$ lysis buffer $(400 \mathrm{mM}$ Tris- $\mathrm{HCl}, \mathrm{pH} 8.0$, $60 \mathrm{mM}$ EDTA, $150 \mathrm{mM} \mathrm{NaCl}$, and $1 \%$ lauroyl sulphate) and transferred to a $1.5 \mathrm{ml}$ microfuge tube; $100 \mu$ of $5 \mathrm{M}$ sodium perchlorate were added and the suspension was incubated at $65^{\circ} \mathrm{C}$ for 20 minutes, after which $1 \mathrm{ml}$ of chloroform (at $-20^{\circ} \mathrm{C}$ ) was added and the suspension was incubated at room temperature for 10 minutes with occasional shaking. After centrifugation for five minutes at $1.2 \times 10^{4} \mathrm{~g}$ the upper layer was transferred to a clean tube and $40 \mu \mathrm{l}$ of silica suspension were added (Nucleon II; Scotlab, Strathclyde, UK). Following centrifugation for five minutes to pellet the silica, $500 \mu \mathrm{l}$ of the supernatant was transferred to another clean tube and $1 \mathrm{ml}$ of $100 \%$ ethanol (at $-20^{\circ} \mathrm{C}$ ) was added to precipitate the DNA. The precipitate was pelleted by centrifugation, washed with $70 \%$ ethanol (at $-20^{\circ} \mathrm{C}$ ), and resuspended overnight in $100 \mu \mathrm{l}$ of $10 \mathrm{mM}$ Tris-OH/1 mM EDTA, pH 7.5 (TE). Spectrophotometry (Gene Quant RNA/DNA Calculator, Pharmacia, Cambridge, UK) was used to determine the DNA concentration of each sample.

ISOLATION OF DNA FROM CLINICAL MATERIAL DNA was isolated from the bronchoalveolar lavage fluid of HIV positive patients as described by Verweij et $a l^{19} ; 100 \mu \mathrm{l}$ of resuspended pellet were added to a microcentrifuge tube two thirds filled with $0.5 \mathrm{~mm}$ zirconium beads. Cell destruction was achieved

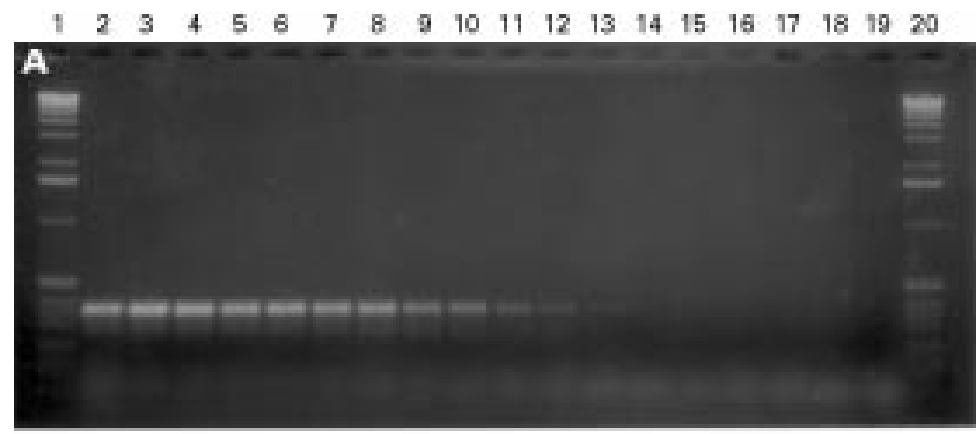

$\mathbf{B}$

Figure 1 A half-log dilution series of $A$ fumigatus DNA was amplified with primers Asp 1 and Asp 2 and detected by agarose gel electrophoresis $(A)$ and Southern blotting $(B)$. Lanes 1 and 20, $1 \mathrm{~kb}$ molecular weight marker. Lane 2, 3.63 $\mu$ g; lane 3, $1.15 \mu \mathrm{g}$; lane 4, 363 ng; lane 5, 115 ng; lane 6, 36.3 ng; lane 7, 11.5 ng; lane 8, 3.63 ng; lane 9, 1.15 ng; lane 10, 363 pg; lane 11, 115 pg; lane 12, 36.3 pg; lane 13, 11.15 pg; lane 14, 3.63 pg; lane 15, 1.15 pg; lane 16, $363 \mathrm{fg}$, lane 17, $115 \mathrm{fg}$; lanes 18 and 19, negative polymerase chain reaction controls. by shaking at $6000 \mathrm{rpm}$ for 160 seconds in a Mini Beadbeater (Biopspec Products, Bartlesville, Oklahoma, USA). Nucleic acids were purified with L6 buffer (10 M guanidinium thiocyanate, $0.1 \mathrm{M}$ Tris- $\mathrm{HCl}, \mathrm{pH} 6.4,0.2 \mathrm{M}$ EDTA, 2.6\% (wt/vol) Triton X-100) and $40 \mu \mathrm{l}$ silica particles (Sigma, St Louis, Missouri, USA) and then washed twice with L2 buffer (10 M guanidinium thiocyanate, $0.1 \mathrm{M}$ Tris$\mathrm{HCl}, \mathrm{pH}$ 6.4). After washing twice with $70 \%$ (vol/vol) ethanol and once with $100 \%$ acetone, DNA was resuspended for one hour at $56^{\circ} \mathrm{C}$ in $100 \mu \mathrm{l}$ of sterile distilled water.

POLYMERASE CHAIN REACTION

A region of the fungal $18 \mathrm{~S}$ ribosomal DNA was amplified. Fifty-microlitre reaction mixtures were set up consisting of buffer $(50 \mathrm{mM} \mathrm{KCl}$, $10 \mathrm{mM}$ Tris-HCl, $\mathrm{pH}$ 9.0, 1.0\% Triton X-100; Promega, Southampton, UK); $1.0 \mathrm{mM} \mathrm{MgCl}_{2}$ (Sigma-Aldrich Chemical Company, Poole, UK); $0.2 \mathrm{mM}$ dNTP (Immugen International, Sunderland, UK), and $1 \mathrm{U}$ of Taq DNA polymerase (HT Biotechnology, Cambridge, UK); 80 pmol each of primer, ${ }^{11}$ Asp1 5'CGGCCCTTAAATAGCCCGGTC-3', and biotin labelled Asp2 (5'-biotin) 5'ACCCCCCTGAGCCAGTCCG-3' (Cruachem, Glasgow, UK), and $5 \mu$ of template DNA were then added to the reaction mix. Amplification was performed in a programmable thermal cycler (Progene; Techne, Cambridge, UK) under the following conditions: five minutes at $94^{\circ} \mathrm{C}$ followed by 40 cycles of one minute at $94^{\circ} \mathrm{C}$, one minute at $62^{\circ} \mathrm{C}$, and one minute at $72^{\circ} \mathrm{C}$. Negative controls of reaction mix without template DNA were included in each reaction.

ANALYSIS OF AMPLIFIED DNA

Aliquots of product $(10 \mu \mathrm{l})$ were analysed by electrophoresis on a $1.5 \%$ agarose gel and visualised by ultraviolet light after staining with $0.5 \mu \mathrm{g} / \mathrm{ml}$ ethidium bromide. Gels were blotted overnight onto a nylon membrane which was hybridised with a digoxigenin-11-dUTP (DIG) labelled aspergillus specific oligonucleotide probe, ${ }^{11}$ (Asp-p) 5'-ATGGAAGTGCG CGGCAATAAC-3'. Hybridisation $(0.6 \mathrm{M}$ $\mathrm{NaCl}, \quad 0.06 \mathrm{M}$ sodium citrate, $0.1 \%$ N-lauroylsarcosine, $0.02 \%$ sodium dodecyl sulphate, $1 \%$ blocking reagent, $10 \mathrm{pmol} / \mathrm{ml}$ probe) for four hours at $46^{\circ} \mathrm{C}$ was followed by colorimetric detection..$^{20}$ Briefly, after washing the membrane in maleic acid buffer $(100 \mathrm{mM}$ maleic acid, $150 \mathrm{mM} \mathrm{NaCl}, \mathrm{pH} 7.5 ; 0.3 \%$ (vol/ vol) Tween 20 ), it was blocked with $1 \% \mathrm{wt} / \mathrm{vol}$ blocking reagent. After binding of the antidigoxigenin-AP antibody, colour substrate solution was added and the colour allowed to develop. Blocking reagent, antibody, and colour substrate solutions were supplied by Boehringer Mannheim UK (Diagnostics and Biochemicals, Lewes, East Sussex, UK).

MICROTITRE PLATE DETECTION OF PCR PRODUCTS

Amplified product was also detected in a streptavidin coated microtitre plate format similar to that described by Roymans et al. ${ }^{17}$ 


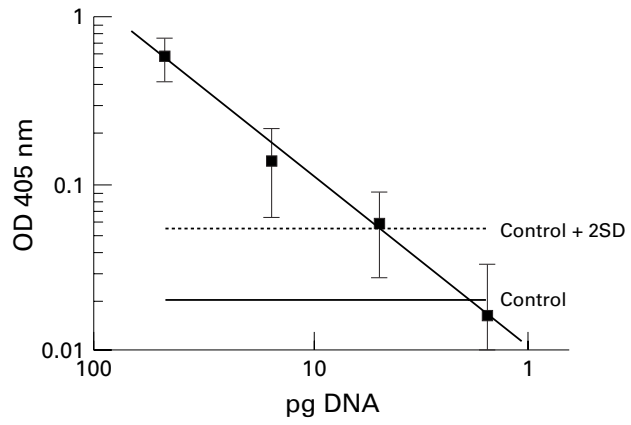

Figure 2 A half-log dilution series of $A$ fumigatus DNA was amplified, captured by streptavidin binding to a microtitre well, and detected colorimetrically. Each dilution was amplified $10 \times$ and the $\log _{10}$ mean $O D_{405}$ was plotted against the $\log _{10}$ of the original DNA concentration. The mean of 30 negative controls plus 2 standard deviations was included as the cut off for a positive polymerase chain reaction result.

Briefly, $20 \mu \mathrm{l}$ of biotin labelled product was diluted $1 / 10$ in $1 \times$ SSC $-0.5 \%$ Tween $20 ; 200$ $\mu \mathrm{l}$ of diluted product were added to a 96 well streptavidin coated microtitre plate (Boehringer Mannheim UK) and incubated for 30 minutes at $37^{\circ} \mathrm{C}$ on a microtitre plate shaker at $1000 \mathrm{rpm}$ (IKA Labortechnik, Staufen, Germany). Antibody and buffers for detection were supplied as part of the PCR-ELISA DIG detection kit (Boehringer Mannheim UK). The method for detection was adapted as follows: wells were washed (Well Wash 4; Denley Instruments, Billingshurst, Sussex, UK) four times with washing buffer and incubated for 10 minutes at room temperature with $200 \mu \mathrm{l}$ of $0.1 \mathrm{M} \mathrm{NaOH}$. Wells were washed four times, then incubated with shaking for one hour at $37^{\circ} \mathrm{C}$ with $200 \mu \mathrm{l}$ of $10 \mathrm{pmol} / \mathrm{ml} \mathrm{DIG}$ labelled Asp-p probe. Wells were washed four times to remove unbound probe and incubated with shaking for 30 minutes at $37^{\circ} \mathrm{C}$ with 200 $\mu \mathrm{l}$ of $0.1 \mathrm{U} / \mathrm{ml}$ anti-digoxigenin peroxidase diluted in conjugate buffer. After washing four times the hybridisation signal was detected by incubating wells with shaking for 20 minutes at $37^{\circ} \mathrm{C}$ with $200 \mu \mathrm{lmg} / \mathrm{ml}$ of 2,2 azino-di [3-ethylbenzthiazoline sulphonate] (ABTS). The absorbence of the wells was read at $405 \mathrm{~nm}$ (Titertek Multiskan MC; IQ (Bio), Cambridge, UK). The absorbence of ABTS alone was subtracted from the value of each test sample.

Table 1 Specificity of microtitre plate detection of A fumigatus DNA from bronchoalveolar lavage specimens

\begin{tabular}{|c|c|c|c|c|c|c|c|}
\hline Patient & (Myco)bacteriology & Parasitology & $\begin{array}{l}\text { Virology } \\
\text { (culture) }\end{array}$ & Mycology & $P C R$ & Blot & $\begin{array}{l}\text { Microtitre } \\
\text { plate } \\
\text { detection }\end{array}$ \\
\hline 1 & $\begin{array}{l}\text { Haemophilus } \\
\text { influenzae }\end{array}$ & - & - & $\begin{array}{l}\text { Penicillium } \\
\text { spp }\end{array}$ & + & - & - \\
\hline 2 & Mycobacterium spp & PCP & CMV, RSV & $\begin{array}{l}\text { Penicillium } \\
\text { spp }\end{array}$ & + & - & - \\
\hline 3 & - & PCP & CMV & - & - & - & - \\
\hline 4 & - & - & CMV & - & - & _- & - \\
\hline 5 & - & - & HSV1 & - & - & - & - \\
\hline 6 & - & - & - & A fumigatus & + & + & + \\
\hline 7 & $\begin{array}{l}\text { Hemolytic } \\
\text { streotococci } \\
\text { Lancefield group G, } \\
\text { Stapylococcus aureus }\end{array}$ & PCP & CMV, HSV1 & $C$ albicans & - & - & - \\
\hline 8 & $\begin{array}{l}\text { Mycobacterium } \\
\text { tuberculosis }\end{array}$ & - & - & - & - & - & - \\
\hline
\end{tabular}

^Atypical, non-speciated mycobacterium.

PCP, Pneumocystis carinii; CMV, cytomegalovirus; RSV, respiratory syncytial virus; HSV1, herpes simplex virus type 1 .
DETERMINATION OF DETECTION LIMITS

DNA of spectrophotometrically determined concentration was serially diluted beyond the limits of detection. PCR was performed as described above, and detection was performed by agarose gel electrophoresis, Southern blotting, and plate hybridisation methods. $\mathrm{OD}_{405}$ values are expressed as the mean (SD).

\section{Results}

PRIMER SELECTION

Primers Asp1 and Asp $2^{11}$ were selected from a study of published reports on the basis of target suitability (rDNA of Aspergillus species) and reported sensitivity.

\section{PCR DETECTION LIMITS}

The limit of detection of aspergillus DNA by PCR using ethidium bromide stained agarose gel electrophoresis was $15 \mathrm{pg}$ of DNA (fig 1A). Southern blotting and hybridisation with an Aspergillus specific probe increased the sensitivity of detection to $1.5 \mathrm{pg}$ (fig $1 \mathrm{~B}$ ). The two bands seen on the ethidium bromide stained gel and Southern blot presumably represent a polymorphism in some copies of the rDNA repeat target. When extracted DNA was stored dissolved in TE at $4^{\circ} \mathrm{C}$ it was found that after seven to 14 days' storage the detection limit of the dilution series fell 10-fold. Storing DNA at $4^{\circ} \mathrm{C}$ as a precipitate in $100 \%$ ethanol and dissolving in TE shortly before amplification maintained the sensitivity of detection, a reproducible detection limit being obtained after four months of storage.

MICROTITRE PLATE OD $_{405}$ FOR PCR DETECTION Using microtitre plate detection, the mean (SD) $\mathrm{OD}_{405}$ of 30 PCR negative controls was 0.02 (0.017), and an $\mathrm{OD}_{405}$ value of 0.056 (mean negative control plus 2 standard deviations) was taken as the cut off point for a positive result (fig 2). To optimise the microtitre plate detection, a half $\log$ dilution series of $A$ fumigatus DNA was amplified and detected under various conditions. Hybridisation for one hour at $37^{\circ} \mathrm{C}$ with $10 \mathrm{pmol} / \mathrm{ml}$ probe was found to be optimal. For example, increasing hybridisation time to 90 minutes decreased the mean $\mathrm{OD}_{405}$ of PCR product amplified from 15 pg DNA by 0.79 . The speed and type of shaking strongly affected the results: it was found that reciprocal shaking at $1000 \mathrm{rpm}$ gave the strongest signal. Increasing shaking speed to $1100 \mathrm{rpm}$ produced more variable results, and tilting the plate at $50 \mathrm{rpm}$ decreased the mean $\mathrm{OD}_{405}$ of $15 \mathrm{pg}$ amplified DNA by 1.09 .

Under optimal conditions, using a serial dilution of Aspergillus DNA a mean of $5 \mathrm{pg}$ could be detected (fig 2). The signal from the microtitre plate detection was proportional to the amount of DNA in the PCR reaction on a $\log$ - log scale between 100 and 1 pg of DNA. DNA amounts greater than $100 \mathrm{pg}$ produced an $\mathrm{OD}_{405}$ reading of more than 2.00 and were therefore off the linear part of the graph in fig 2 .

DETECTION OF DNA FROM CLINICAL MATERIAL Of the eight bronchoalveolar lavage samples extracted, three were positive and five negative 
for aspergillus DNA by PCR. Microtitre plate hybridisation gave an $\mathrm{OD}_{405}>2.00$ for sample 6 ; all other samples were negative. Southern blotting was also positive for sample 6 and this was the only sample from which $A$ fumigatus was cultured (table 1).

\section{Discussion}

Current tests used for the diagnosis of invasive aspergillosis lack sensitivity and specificity, and positive results are often obtained too late to influence patient management. The sensitivity of the PCR for the detection of aspergillus DNA in our assay is very high. Fifteen picograms of DNA can be detected by agarose gel electrophoresis, and Southern blotting using an aspergillus specific probe increases the sensitivity 10 -fold. This sensitivity is comparable with that obtained by other groups researching the PCR detection of $A$ fumigatus DNA. ${ }^{8-121415}$ Microtitre plate detection of PCR products has the same sensitivity and specificity as Southern blotting. ${ }^{17}$ Our study confirms the sensitivity of microtitre plate detection of $A$ fumigatus DNA. However, results are obtained in one day rather than the three days required for agarose gel electrophoresis, blotting, hybridisation, and detection. This format does not affect the specificity of the assay since no cross reactivity has been observed with DNA extracts from bronchoalveolar lavage. Patients culture positive for Candida albicans, Penicillium sp, Mycobacterium tuberculosis and other upper respiratory tract pathogens (table 1) were negative by microtitre plate detection. In addition, the microtitre plate format of the assay will allow the rapid incorporation of the test into diagnostic laboratories routinely performing ELISA antigen assays. ${ }^{18}$ A large scale prospective study comparing the microtitre plate detection with other diagnostic tests on specimens from patients at risk of invasive aspergillosis is required to determine the usefulness of this assay and is currently underway.

1 Cohen J. Clinical manifestations and management of aspergillosis in the compromised patient. In: Warnock DW,
Richardson MD, eds. Fungal infection in the compromised patient, 2nd ed. Chichester: John Wiley, 1991:118-39.

2 Kwon-Chung KJ, Bennet JE. Aspergillosis. In: KwonChung KJ, Bennet JE, eds. Medical mycology. Philadelphia: Lea and Febiger, 1992:201-47.

3 Mullins J, Seaton A. Fungal spores in lung and sputum. Clin Allergy 1978;8:525-33.

4 Hopwood V, Evans EGV. Serological tests in the diagnosis and prognosis of fungal infection in the compromised patient. In: Warnock DW, Richardson MD, eds. Fungal infection in the compromised patient, 2nd ed. Chichester: John Wiley, 1991:312-40.

5 Hopwood V, Johnson EM, Cornish JM, et al. Use of pastorex aspergillus antigen latex agglutination test for the diagnosis of invasive aspergillosis. F Clin Pathol 1995;48:21013.

6 Verweij PE, Stynen D, Rijs AJMM, et al. Sandwich enzymelinked immunosorbent assay compared with Pastorex latex agglutination test for diagnosing invasive aspergillosis in immunocompromised patients. $\mathcal{F}$ Clin Microbiol 1995;33. 1912-14.

7 Mitchell TG, Sandin RL, Bowman BH, et al. Molecular mycology: DNA probes and applications of PCR technology. F Med Vet Mycol 1994;32:351-66.

8 Bretagne S, Costa JM, Marmorat-Khuong A, et al. Detection of Aspergillus species DNA in BAL samples by PCR. F Clin Microbiol 1995;33:1164-8.

9 Haynes KA, Westering TJ, Fell JW, et al. Rapid detection and identification of pathogenic fungi by PCR amplification of large subunit ribosomal DNA. $7 \mathrm{Med}$ Vet Mycol 1995;33:319-25.

10 Hopfer RL, Walden P, Setterquist S, et al. Detection and differentiation of fungi in clinical specimens using PCR amplification and restriction enzyme analysis. $7 \mathrm{Med}$ Vet Mycol 1993;31:65-75.

11 Melchers WJG, Verweij PE, Vanden Hurk P, et al. General primer mediated PCR for detection of Aspergillus species. $\mathcal{F}$ Clin Microbiol 1994;32:1710-17.

12 Reddy LV, Kumar A, Kurup VP. Specific amplification of $A$. fumigatus DNA by PCR. Mol Cell Probes 1993;7:121-6.

13 Sandhu G S, Kline BC, Stockman L, et al. Molecular probes for diagnosis of fungal infections. F Clin Microbiol 1995;33: 2913-19.

14 Spreadbury C, Holden D, Aufavre-Brown A, et al. Detection of Aspergillus fumigatus by PCR. F Clin Microbiol 1993;31: 615-21

15 Tang CM, Holden DW, Aufavre-Brown A, et al. The detection of Aspergillus species by PCR and its evaluation in BAL fluid. Am Rev Respir Dis 1993;148:1313-17.

16 Einsele H, Hebart H, Roller G, et al. Detection and identification of fungal pathogens in blood using molecular probes. 7 Clin Microbiol 1997;35:1353-60.

17 Roymans RTMJ, Onland G, Postma BH. One-day detection of PCR amplified Chlamydia trachomatis DNA in clinical samples: ELISA versus Southern blot hybridisation. $\mathcal{f}$ Clin Pathol 1996;49:581-3.

18 Hee Shin J, Nolte FS, Morrison CJ. Rapid identification of Candida species in blood cultures by a clinically useful PCR method f Clin Microbiol 1997;35:1454-9.

19 Verweij PE, Meis JFGM, van den Hurk P, et al. Polymerase chain reaction as a diagnostic tool for invasive aspergillosis: evaluation in bronchoalveolar lavage fluid from low risk patients. Serodiagn Immunother Infect Dis 1994;6:203-8.

20 Boehringer Mannheim. The DIG system user's guide for filter hybridization. Mannheim: Boehringer Mannheim $\mathrm{GmbH}$, Biochemica 1995:61-2. 